\title{
ACCOUNTING TRAINING IN UMKM SOUTH MERUYA
}

\author{
Harnovinsah and Lawe Anasta \\ Universitas Mercu Buana Jakarta, Indonesia. \\ dr.harnovinsah@gmail.com
}

\begin{abstract}
Accounting processes are a very important process in an organization. Accounting is a self-discipline that learns about financial bookkeeping especially within the organization. The main function of this accounting is as the financial informer of a particular organization whether it is business or non business organization. Accounting is an art that cover the recording, classification and proper summarize and the recording is stated in the currency unit. Transactions carried out and then recorded at least economically and financially so easily expressed in the currency unit.
\end{abstract}

Keywords: UMKM, Accounting, SAK ETAP

\section{INTRODUCTION}

SMES are short for micro, small and medium enterprises. SMES are governed by LAW number 20 year 2008 about micro, small and medium enterprises. The following excerpts from the contents of LAW 20/2008.

a. Micro enterprise is a productive business belonging to individual and/or individual business entity that meet micro enterprise criteria as stipulated in this law.

b. Small business is a standalone productive economic business, conducted by an individual or business entity that is not a subsidiary or non-branch of a company owned, mastered, or becomes part either directly or not From medium enterprises or large enterprises that meet the small business criteria as intended in this law.

c. Medium Enterprises is a self-productive economic endeavor that is done by individuals or business entities who are not subsidiaries or branches owned, controlled, or part of either direct or not With a small business or a large undertaking with net worth or annual sales proceeds as set forth in this law.

Micro enterprises, small business, and medium enterprises are business activities that are able to expand employment and provide broad economic services to the community, and can play a role in the process of equalization and increase in community income, Promote economic growth, and play a role in realizing national stability. In addition, micro enterprises, small business, and medium enterprises are one of the main pillars of the national economy that must acquire the main opportunities, support, protection, and development of widest as a form of strict alignments to economic efforts People, as well as in home industry activities and joint ventures by not ignoring the role of the big business and state owned enterprises.

Essentially micro, small and medium-sized entities are unsignificant public accountability entities, as defined in the financial Accounting standards of the entity without public accountability Micro, small, and medium enterprises as stipulated in the prevailing laws and regulations in Indonesia, for a period of two consecutive years.

Accounting processes are a very important process in an organization. Accounting is a self-discipline that learns about financial bookkeeping especially within the organization. Activities in accounting itself may include identification, recording and information delivery. In accounting reports or later more often referred to as financial statements, there are other reports such as income statement, depreciation report, capital change report, and balance sheet. This financial statement will make it easy for every decision maker here to be a policy stakeholder in order to appropriately make informed decisions through the information.

The main function of this accounting is as the financial informer of a particular organization whether it is business or non business organization. From the accounting report, it can then be seen the financial position of an organization and can see the financial health of an organization. Recording in accounting is nominally or in monetary form. This makes it easier to record and estimate. So all assets in the organization will be assessed with money. This will later be easier to predict the wealth of an organization. But be aware that accounting is not only useful for the organization and the services of accountants, but accounting is also used in everyday life without you realizing it. Whatever your background will all be separated from its name accounting process. 
Accounting is an art that cover the recording, classification and proper summarize and the recording is stated in the currency unit. Transactions performed and then recorded at least economically and financially so easily expressed in currency units.

It can therefore be concluded that accounting is the process of recording, classification and presentation of information. Once again the financial information contained in this accounting report is very beneficial for the assessment and decision making for the parties in need. Accounting is very beneficial for business activities and also for everyday life. This is the benefit of accounting.

1. As information to the needy party

In direct party organizations need This accounting information is a management party. The organization's management will look at the financial information available in the accounting reports and can then take some decisions such as controlling the organization, coordinating the Organization for the better and for Plan what policies will be taken in the future.

2. Organization or individual evaluation process

In addition to the actual organization accounting This is also indispensable by individuals and individual as a material of self-evaluation finances. By doing the accounting itself you will be able to understand your financial situation and after that you can plan what is the best in the future with existing financial conditions.

\section{As accurate evidence of the organization}

If there are some parties that interfere with financial problems such as workers who are not satisfied with the salary given and demand for a salary increase while the Organization can not. If this is the case, the organization can conduct consultation with the workers and show the recording of the organization accounting.

\section{Used in households}

Accounting process can also be done by household unit where the recording is done in accordance with the existing transactions so that it can control the income and expenses made. As a housewife should also be ready to become an accountant without salary per month because accounting is very important so that household finances can be better and better planned.

When our business is already running, when our business has begun to reveal its shape. Sometimes we start thinking about further fixing your business bookkeeping. Nowadays many business people, especially small and medium enterprises who have been running their business but still do not have a neat bookkeeping, so it is often difficult to analyze business trend, cash flow and level Business development.

The objective of this activity is the SME actors in the village of South Meruya West Jakarta.

\section{SOLUTION AND TARGET}

Based on the problems that have been outlined in the analysis of the situation above, then the solution to be done is to provide a supply to SMES actors in the village South Meruya West Jakarta so that they can easily understand and know accounting so as to make reports of financial liabilities.

An external Target expected from this activity is the SMES actors in the village of South Meruya West Jakarta, so that they can understand and skilled in the responsibility of personal and family finances in making a financial statement. For more details the target external achievement plan can be seen in the following table:

\section{METHOD}

The methods used in this activity are in the form of training. The participants were given material training on the introduction of basic accounting in South Meruya Village office. Participants were immediately taught how to understand and create a simple financial report and given the training module and motivated to actively discuss to convey all the problems related to simple accounting understanding.

\section{IDENTIFICATION AND FORMULATION OF PROBLEMS}

The following formulation of the problems identified in this activity are:

1. How to understand accounting well?

2. How do I make a simple bookkeeping?

3. How do I create financial accountability for personal and family self? 


\section{PURPOSE OF ACTIVITY}

This activity aims to provide training to SMES counterparts in South Meruya so that participants gain knowledge and skills, including:

1. Understanding Accounting.

2. Understand simple bookkeeping.

3. Make a simple financial accountability.

\section{BENEFITS OF ACTIVITIES}

This training activity is useful to improve the knowledge, understanding and skills of MSME actors in South Meruya village of West Jakarta, regarding simple accounting and bookkeeping that are expected to understand and make simple bookkeeping So it can manage the business finances well.

\section{EVALUATION PLAN}

Trainees will be evaluated by asking them to resolve cases related to simple bookkeeping accounting cycles, as well as requesting their conclusions on the training material. Participants are also free to discuss or communicate or consult a team of community service in the event that community dedication is conducted.

\section{RESULT}

The Community devotion activity resulted in an increase in knowledge about the understanding of financial statements as a tool of financial responsibility in the community organization well for the Society in the Indonesian South Meruya. Initially the participants were still unclear what and how the financial statements, the benefits of financial statements, account for the finances of community organizations. The trainees will be evaluated by requesting their conclusions on the material assessment of the understanding of the socialization of financial statements, financial accountability and financial statements benefits. Conclusion results can be input for the community in South Meruya village to understand the financial statements and how to account for financial statements in community organizations. In conclusion, the participants were very enthusiastic and felt to receive excellent benefits for the implementation of this activity.

\section{CONCLUSION AND ADVICE}

Participants are expected to benefit from the community service Program. This benefit is the understanding of financial statements as well as the benefits of financial statements and account with ease and clarity. From the results of this activity can be concluded the benefits received by the community in South Meruya village is that they can understand the financial statements, benefits of financial statements, community organizations and responsible financial reports on Community organizations. Where the community previously did not understand what the financial statements, the importance or benefits of financial statements, accountability of financial statements as well, because so far they understand the financial statements that make the company and government but not Understanding the benefits and importance of financial statements in life.

The wise Solution understands the financial statements by providing the case or practice of explaining the financial statements, examples of financial statements, the benefits of the financial statements and bookkeeping is what it is and provides solutions to the problems that exist.

\section{REFERENCES}

Ariefiansyah, Ryan dan Miyogi Margi utami. 2013. Membuat Laporan Keuangan Gampang. Jakarta: Dunia Cerdas.

Darsono dan Ashari. 2005. Pedoman Praktis Memahami Laporan Keuangan. Yogyakarta: Andi Offset.

Warren, Reeve, Fees. 2013. Accounting. IFRS Edition. John Wiley \& Sons.Soemanagara, R.D. (2006). Strategic Marketing Communication. Bandung: Penerbit Alfabeta. 